\title{
FIRST RECORD OF THE INDIAN OCEAN TWOSPOT CARDINALFISH, CHEILODIPTERUS NOVEMSTRIATUS (ACTINOPTERYGII: PERCIFORMES: APOGONIDAE), FROM TURKISH MARINE WATERS
}

\author{
Cemal TURAN ${ }^{1 *}$, Deniz ERGUDEN ${ }^{1}$, Necdet UYGUR ${ }^{1}$, Mevlut GURLEK ${ }^{1}$, \\ Zeliha A. ERDOGAN ${ }^{2}$, Bektas SONMEZ ${ }^{3}$, Ali UYAN¹', Serpil KARAN¹, and Servet A. DOGDU1 \\ ${ }^{1}$ Faculty of Marine Sciences and Technology, Mustafa Kemal University, Iskenderun, Hatay, Turkey \\ ${ }^{2}$ Cumhuriyet University Suşehri Timur Karabal Vocational School, Fisheries Program, Sivas, Turkey \\ ${ }^{3}$ Ballkesir University, Science Faculty, Biology Department, Ballkesir, Turkey
}

Turan C., Erguden D., Uygur N., Gurlek M., Erdogan Z.A., Sonmez B., Uyan A., Karan S., Dogdu S.A. 2015. First record of the Indian Ocean twospot cardinalfish, Cheilodipterus novemstriatus (Actinopterygii: Perciformes: Apogonidae), from Turkish marine waters. Acta Ichthyol. Piscat. 45 (3): 319-322.

\begin{abstract}
Indian Ocean twospot cardinalfish, Cheilodipterus novemstriatus (Rüppell, 1838), is recorded for the first time from the Turkish marine waters. Two specimens of $C$. novemstriatus were sampled with a purse seiner on 1 December 2014, and also a school of $C$. novemstriatus was photographed during scuba diving at a depth of $13 \mathrm{~m}$ on a rocky surface on 8 December 2014 in the Cevlik coast, Iskenderun Bay, north-eastern Mediterranean of Turkey. With the present report, the number of alien cardinal fish species reported in the Turkish coasts has reached five.
\end{abstract}

Keywords: fish, first country record, Lessepsian migration, colonisation, range extension

Nowadays many alien fish species, which entered the Mediterranean via the Suez Canal, have established dense populations in the north-eastern coastal waters of Turkey (Ergüden and Turan 2013). Some species have become abundant in the eastern Mediterranean ichthyofauna and also acquired an economic importance within the regional fisheries (Bariche et al. 2004).

To date, the family Apogonidae is represented in the eastern Mediterranean Sea by four genera and six species (Golani et al. 2002, Gon and Randall 2003, Froese and Pauly 2014), namely Apogon imberbis (Linnaeus, 1758); Jaydia queketti (Gilchrist, 1903); Jaydia smithi Kotthaus, 1970; Apogonichthyoides pharaonis (Bellotti, 1874); Cheilodipterus novemstriatus (Rüppell, 1838); and Ostorhinchus fasciatus (White, 1790). These five species are of Indo-Pacific origin while only Apogon imberbis is of Atlantic provenance. In recent years, cardinal fish species successfully established in the north-eastern Mediterranean coast of Turkey (Eryilmaz and Dalyan 2006, Goren et al. 2009, Turan 2010) and are now components of the Turkish ichthyofauna (Ergüden et al. 2013).

The Indian Ocean twospot cardinalfish, Cheilodipterus novemstriatus, was first reported in the Mediterranean off Tel Aviv in June 2010 (Goren et al. 2010). Thereafter, Bariche and Azzurro (2012) recorded two specimens off shore, north of Beirut, Lebanon in July-August 2012. Lately, C. novemstriatus was reported to form dense aggregations along the Israeli coasts (Rothman et al. 2013).

In the present report, two specimens of Indian Ocean twospot cardinalfish, Cheilodipterus novemstriatus (Fig. 1) were caught by purse seiner on sandy-muddy bottom at a depth of $15 \mathrm{~m}$ on 1 December 2014 from the near Cevlik harbour, Iskenderun Bay, north-eastern Mediterranean coast of Turkey $\left(36^{\circ} 07^{\prime} \mathrm{N}, 35^{\circ} 54^{\prime} \mathrm{E}\right)$. The collected two specimens were preserved in $4 \%$ formalin and deposited at the ichthyological collection of Marine Science and Technology Faculty, Mustafa Kemal University (Catalogue numbers: MSM-PIS/2014-5 and MSM-PIS/2014-6) (Fig. 1). Moreover, a school of numerous individuals of $C$. novemstriatus were photographed from the same location during scuba diving at a depth of $13 \mathrm{~m}$ on a rocky surface on 7 December 2014 (Fig. 2).

The identification of the specimens collected and observed in the Cevlik province were similar with those previously reported in Israel and Lebanon (Goren et al. 2010, Bariche and Azurro 2012). Morphometric measurements 




Fig. 1. Indian Ocean twospot cardinalfish, Cheilodipterus novemstriatus, from the Cevlik harbour (Iskenderun Bay)

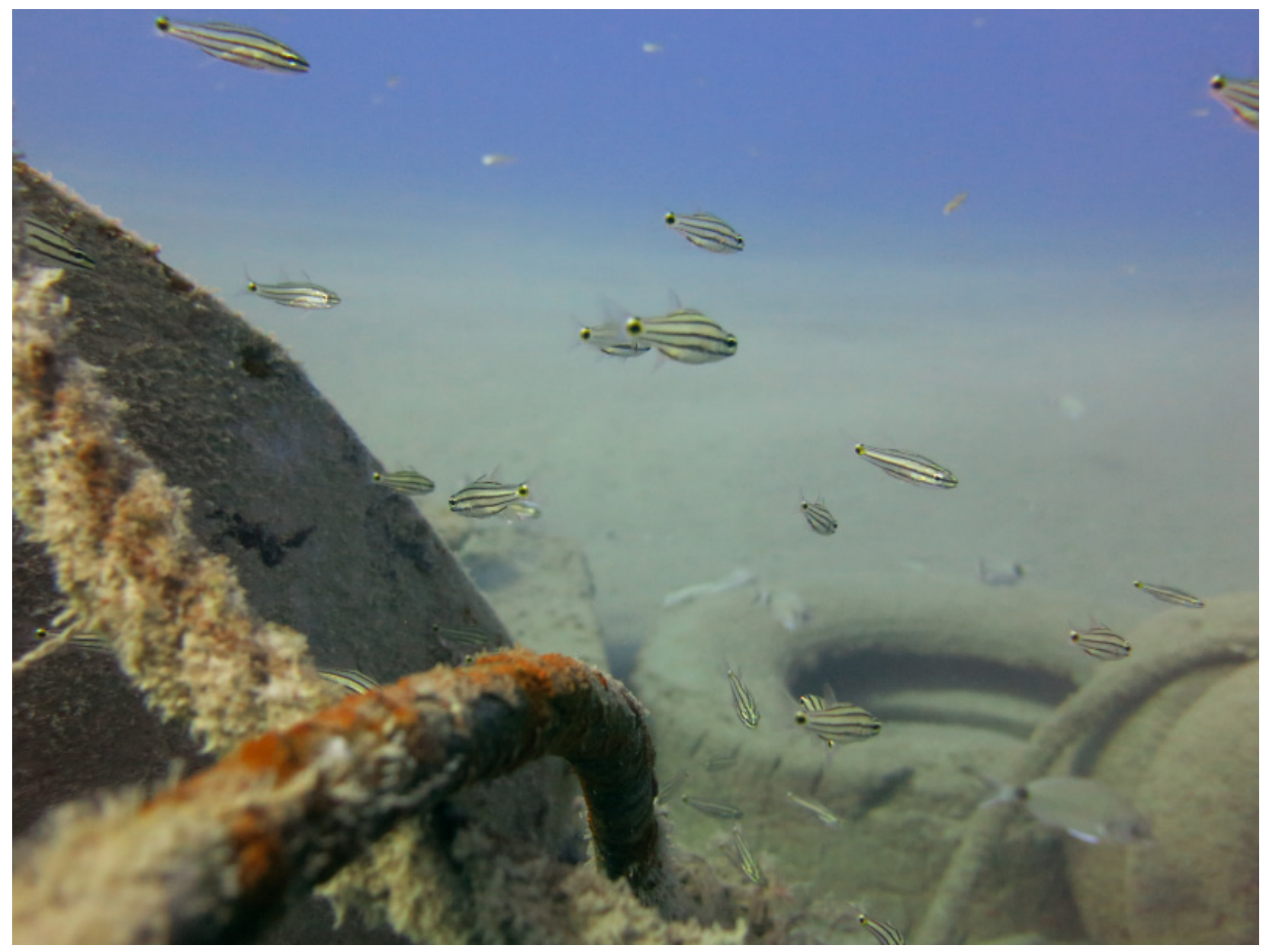

Fig. 2. Underwater photos of Indian Ocean twospot cardinalfish, Cheilodipterus novemstriatus, at Cevlik coast, Iskenderun Bay 
of the specimens were made to the nearest $0.01 \mathrm{~mm}$ using digital calliper. All measurements, counts, the morphological descriptions and colours agree with the descriptions given by Gon and Randall (2003) and Goren et al. (2010).

The presently reported finding constitutes the first record of Cheilodipterus novemstriatus in the Turkish marine waters, thus increasing up to five the total number of alien cardinal fish species reported from the Turkish coastal waters. The occurrence of $C$. novemstriatus in the Mediterranean Sea can be attributed to migration from the Red Sea via the Suez Canal, and the fish were apparently following the northward pathway in the eastern Mediterranean Sea judging from previously reported records (Goren et al. 2010, Bariche and Azzurro 2012, Rothman et al. 2013).

The common size of Cheilodipterus novemstriatus is 2 to $6 \mathrm{~cm}$, however, it can reach up to $8 \mathrm{~cm}$ TL (Randall 1995, Gon and Randall 2003, Froese and Pauly 2014). The length of the two specimens measured in this study was respectively 29.98 and $34.33 \mathrm{~mm}$ (standard length) and 40.78 and $46.75 \mathrm{~mm}$ (total length). All measurements and counts of those specimens of $C$. novemstriatus are given in Table 1.

Cheilodipterus novemstriatus preys on zooplankton and is commonly found in shallow waters of depths ranging from 1 to $10 \mathrm{~m}$, in association with holes and under ledge of corals and rocky reefs (Randall 1995). It is widely distributed throughout the western Indian Ocean, from the Red Sea, through Gulf of Oman to the Persian Gulf (Froese and Pauly 2014). Dense populations on rocky substrate at depths down to $50 \mathrm{~m}$ were sighted in Israel (Brokovich et al. 2008). In the presently reported study, underwater observation (Fig. 2) suggested that there is also dense population of $C$. novemstriatus in Cevlik coast, indicating rapid expansion of this species in the Turkish coasts.

In the last decade, three cardinal fish species rapidly spread and established along the Turkish coasts (Ergüden et al. 2013), and several studies reported a range expan- sion to westwards, along the north-eastern Mediterranean and Aegean Sea coast of Turkey (Gökoğlu et al. 2011a, 2011b, 2012, Filiz et al. 2012). The increase in water temperature has been considered as the main reason for the increasing introductions of tropical fish in the Mediterranean Sea (Galil 2009, Ben Rais Lasram et al. 2010, Golani 2010, Turan 2010, Öztürk and Turan 2014).

The immigration of Red Sea fish species from the Suez Channel is an ongoing process and it continuously affects and changing the local fish community (Golani 1998, Turan 2010). Cheilodipterus novemstriatus will probably be well established like other cardinal fish species in the Iskenderun Bay and along the Mediterranean coast of Turkey in the near future. The Red Sea migrants are continuously changing the fish communities in the eastern Mediterranean Sea. Therefore, the role of this newly established species within the coastal ecosystem, and its effect on local populations should be investigated.

\section{ACKNOWLEDGMENTS}

Our thanks are due to Ahmet Dönmez for his help in providing this specimens.

\section{REFERENCES}

Bariche M., Azzurro E. 2012. New records and establishment of the Indian Ocean twospot cardinalfish Cheilodipterus novemstriatus (Rüppell, 1838) in the Mediterranean Sea. BioInvasions Records 1 (4): 299 301.

DOI: $10.3391 /$ bir.2012.1.4.10

Bariche M., Letourneur Y., Harmelin-Vivien M. 2004. Temporal fluctuations and settlement patterns of native and Lessepsian herbivorous fishes on the Lebanese coast (eastern Mediterranean). Environmental Biology of Fishes 70 (1): 81-90.

DOI: 10.1023/B:EBFI.0000022928.15148.75

Table 1

Morphometric and meristic counts for two specimens of the Indian Ocean twospot cardinalfish, Cheilodipterus novemstriatus, from Turkish marine waters

\begin{tabular}{|c|c|c|c|c|}
\hline Character & $\begin{array}{l}\text { Value } \\
{[\mathrm{mm}]}\end{array}$ & $\begin{array}{l}\text { Value } \\
{[\% \text { TL] }}\end{array}$ & $\begin{array}{c}\text { Value } \\
{[\% \mathrm{HL}]}\end{array}$ & Count \\
\hline Total length (TL) & $46.7-40.8$ & & & \\
\hline Standard length (SL) & & $34.3-30.0$ & & \\
\hline Body depth (BD) & & $21.2-19.6$ & & \\
\hline Head length (HL) & & $20.5-19.8$ & & \\
\hline Eye diameter (ED) & & & $46.1-46.0$ & \\
\hline Interorbital width (IOW) & & & $38.2-38.1$ & \\
\hline Length of dorsal fin basis & & $12.4-8.9$ & & \\
\hline Length of second dorsal fin basis & & $14.0-11.8$ & & \\
\hline Length of anal fin basis & & $17.2-9.7$ & & \\
\hline Longest pectoral fin ray & & $18.4-14.7$ & & \\
\hline Longest pelvic fin ray & & $17.9-16.2$ & & \\
\hline No. of rays in first dorsal fin $\left(D_{1}\right)$ & & & & $7-6$ \\
\hline No. of rays in second dorsal fin $\left(\mathrm{D}_{2}\right)$ & & & & I 9-I 9 \\
\hline No. of rays in anal fin (A) & & & & II $8-$-II 8 \\
\hline No. of rays in pectoral fin $(\mathrm{P})$ & & & & $12-12$ \\
\hline
\end{tabular}


Ben Rais Lasram F., Guilhaumon F., Albouy C., Somot S., Thuiller W., Mouillot D. 2010. The Mediterranean Sea as a 'cul-de-sac' for endemic fishes facing climate change. Global Change Biology 16 (12): 3233-3245. DOI: $10.1111 /$ j.1365-2486.2010.02224.x

Brokovich E., Einbinder S., Shashar N., Kiflawi M., Kark S. 2008. Descending to the twilight-zone: Changes in coral reef fish assemblages along a depth gradient down to $65 \mathrm{~m}$. Marine Ecology Progress Series 371: 253-262.

DOI: $10.3354 /$ meps 07591

Ergüden D., Filiz H., Turan C. 2013. Türkiye denizlerindeki Hint Pasifik kökenli lesepsiyen balık türlerinin 2013 revizyonu ve geçiş yolları. [Revision of 2013 of Indo-Pacific origin of Lessepsian fish species in Turkish Seas and transition pathways.] Pp. 34-43 In: Anonymous (ed.) XVI. Sualtı Bilim ve Teknolojisi Toplantıs1 SBT'2013, 2-3 Kasım 2013, Hatay, Turkey. [In Turkish.]

Ergüden D., Turan C. 2013. Iskenderun ve Mersin Körfezi yabancı balık faunasındaki son gelişmeler. [Recent developments in alien fish fauna of the Gulf of Iskenderun and Mersin.] Biyoloji Bilimleri Araştırma Dergisi 6 (1): 17-22. [In Turkish.]

Eryilmaz L., Dalyan C. 2006. First record of Apogon queketti Gilchrist (Osteichthyes: Apogonidae) in the Mediterranean Sea. Journal of Fish Biology 69 (4): 1251-1254. DOI: $10.1111 / \mathrm{j} .1095-8649.2006 .01185 . \mathrm{x}$

Filiz H., Yapici S., Bilge G. 2012. Apogon queketti (Apogonidae) in the Aegean Sea. Journal of Biological Research-Thessaloniki 18: 297-300.

Froese R., Pauly D. (eds.) 2014. FishBase. [version 07/2014] http://www.fishbase.org

Galil B.S. 2009. Taking stock: Inventory of alien species in the Mediterranean Sea. Biological Invasions 11 (2): 359-372.

DOI: $10.1007 / \mathrm{s} 10530-008-9253-y$

Golani D. 1998. Impact of Red Sea fish migrants through the Suez Canal on the aquatic environment of the eastern Mediterranean. Bulletin of Yale University, Yale School of Forestry and Environmental Studies 103: 375-387.

Golani D. 2010. Colonization of the Mediterranean by Red Sea fishes via the Suez Canal Lessepsian migration. Pp. 145-188. In: Golani D., Appelbaum-Golani B. (eds.) Fish invasions of the Mediterranean Sea: Changes and renewal. Pensoft Publishers, Sofia-Moscow.

Golani D., Orsi Relini L., Massuti E., Quignard J.-P. 2002. CIESM Atlas of exotic species in the Mediterranean. Fishes. Vol. 1. CIESM Publications, Monaco.

Gon O., Randall J.E. 2003. A review of the cardinalfishes (Perciformes: Apogonidae) of the Red Sea. Smithiana Bulletin 1 (1): 1-48.
Gökoğlu M., Özbek E.Ö., Kebapçioğlu T., Balci B.A., Kaya Y. 2011a. The second location records of Apogon smithi and Vanderhorstia mertensi (Pisces) from the Turkish coast of the Mediterranean Sea. Marine Biodiversity Records 3: e83.

DOI: $10.1017 / \mathrm{S} 175526721000076 \mathrm{X}$

Gökoğlu M., Özvarol Y., Balci B.A. 2012. Westward extension of the Indo-Pacific cardinal fish Apogon fasciatus (White, 1790) along the Turkish coast. BioInvasions Records 1 (3): 225-227. DOI: $10.3391 /$ bir.2012.1.3.09

Gökoğlu M., Ünlüsayın M., Balcı B.A., Özvarol Y., Çolak H. 2011b. Two alien fish in the Gulf of Antalya: Apogon queketti Gilchrist, 1903 (Apogonidae) and Champsodon nudivittis (Ogilby, 1895) (Champsodontidae). Zoology in the Middle East 54 (1): 138-140. DOI: 10.1080/09397140.2011.10648888

Goren M., Lipsky G., Brokovich E., Abelson A. 2010. A 'flood' of alien cardinal fishes in the eastern Mediterranean-first record of the Indo-Pacific Cheilodipterus novemstriatus (Rüpell, 1838) in the Mediterranean Sea. Aquatic Invasions 5 (Suppl. 1): S49-S51.

DOI: 10.3391/ai.2010.5.S1

Goren M., Yokes B., Galil B.S., Diamant A. 2009. IndoPacific cardinal fish in the Mediterranean Sea-new records of Apogon smithi from Turkey and A. queketti from Israel. Marine Biodiversity Records 2: e95. DOI: $10.1017 / \mathrm{S} 1755267209001134$

Öztürk B., Turan C. 2012. Alien species in the Turkish seas. Pp. 92-130. In: Tokaç A., Gücü A.C., Öztürk B. (eds.) The state of the Turkish fisheries. Publication No. 34. Turkish Marine Research Foundation, Istanbul, Turkey.

Randall J.E. 1995. Coastal fishes of Oman. University of Hawaii Press, Honolulu, HI, USA.

Rothman B.-S.S., Goren M., Galil B.S. 2013. Cheilodipterus novemstriatus (Rüppell, 1838) along the Levantine coast of the Mediterranean Sea: A forthcoming invasion? BioInvasions Records 2 (1): 85-88. DOI: $10.3391 /$ bir.2013.2.1.15

Turan C. 2010. Status and trend of Lessepsian species in marine waters of Turkey. Pp. 109-118. In: Anonymous (ed.) FAO-EastMed Technical Document 4; GCP/INT/041/EC-GRE-ITA/TD-04.

Turan C., Yaglioglu D., Erguden D., Gurlek M., Sonmez B. 2010. First record of the broad-banded cardinal fish Apogon fasciatus (White, 1790) from Turkey. Mediterranean Marine Science 11 (2): 369-372. DOI: $10.12681 / \mathrm{mms} .85$

Received: 20 November 2014 Accepted: 1 April 2015 Published electronically: 30 September 2015 